\title{
Synthesis of nanomaterial from industrial waste and its application in environmental pollutant remediation
}

\author{
Jacob Vinitha Judith ${ }^{\dagger}$, Namasivayam Vasudevan \\ Centre for Environmental Studies, Anna University, College of Engineering Guindy, Chennai-600025, Tamil Nadu, India
}

\begin{abstract}
Increased productions of waste from industries have persuaded in sustainable and naturally stable methods to reuse the waste. Utilization of wastes for the synthesis of nanomaterial is of significant importance due to its extensive variety of uses in various industrial sectors. This review focuses on potential options available for nanomaterial synthesis from waste produced by industrial activities and manufacturing processes. Possible application of industrial waste derived nanomaterial for the expulsion of organic and inorganic contaminants is discussed. Furthermore, the future opportunities and challenges in this emerging research area of converting industrial waste to nanomaterials are addressed.
\end{abstract}

Keywords: Industrial waste, Nanomaterial, Pollutant, Recovery, Remediation

\section{Introduction}

Industrialization and urbanization has led to billion tons of toxic waste generation annually by creating significant burden on the environment [1]. Therefore effective treatment technology development and finite resources conservation is essential when the limiting resources of the earth, the limited land availability for waste disposal and its adverse impact on environment is taken into account [2]. In the waste generated from various industrial sector, there exist large quantities of secondary raw materials that could be used in wide range of applications [3]. In order to safeguard the environment, waste minimization, separation and recycling processes should be developed [4]. However industrial wastes released from different manufacturing processes exhibit hazardous characteristics and are mostly composed of heavy metals such as lead, cadmium, copper, arsenic, nickel, chromium, zinc and mercury creating significant burden on the environment. In particular, the main contributors for the release of toxic heavy metals in the waste streams include Mining, electroplating, metal processing, textile, battery manufacturing, tanneries, paint manufacturing, paper and pulp industry $[5,6]$. The industrial wastes with heavy metals, toxic chemicals, and dyes and has the ability to accumulate in human bodies and cause serious diseases and physical disorders. Among which, heavy metals were considered as the most hazardous. For example, short term exposure to high dosage of chromium causes irritation at the site of contact, affects nasal mucosa and cause ulcers on the skin. Chromium utilizing industries such as paint pigment and paper industries, mining, electroplating, leather tanning, metal processing, textile, dyeing and steel fabrication are some of sources of chromium pollution. Lead pollution is caused from steel waste, battery waste and petrol where, lead gets accumulated in the kidney, brain, muscles, and bones causing hypertension, kidney and brain damage [7]. Nanomaterial synthesis from industrial waste is an effective way for treatment and recycle of waste which conforms to the concepts of minimum waste generation and wealth from waste [8]. Since, nanoparticles present unique properties like high specific surface area and reactivity, it helps in detection and removal of diverse targets, including chemicals, pollutant gases, organic pollutants, and biological substrates (e.g. bacteria, virus, antibiotics). Currently, industrial waste utilization as starting material for synthesizing nanomaterial has gained interest due to attractive economic returns and its path towards sustainable development [9]. Electroplating industrial waste is one of the highly used waste for the synthesis of waste derived nanomaterials due to high level enrichment with organic matter and metals (Fe, $\mathrm{Cr}$, $\mathrm{Cu}, \mathrm{Ni}, \mathrm{Pb}, \mathrm{Mn}, \mathrm{Sn}, \mathrm{Ag}$ etc.) in various forms such as mixed oxides, hydroxides, sulfates, silicates and phosphates, that are potential precursors to advanced catalysts [10]. At present, the conventional
This is an Open Access article distributed under the terms of the Creative Commons Attribution Non-Commercial License (http://creativecommons.org/licenses/by-nc/3.0/) which permits unrestricted non-commercial use, distribution, and reproduction in any medium, provided the original work is properly cited.

Copyright (C) 2022 Korean Society of Environmental Engineers
Received December 02, 2020 Accepted March 01, 2021

${ }^{\dagger}$ Corresponding author

E-mail: vinithajudith@gmail.com

Tel: +91-9003364847

ORCID: 0000-0002-1336-129X 
treatment methods for electroplating waste are landfill, brick making, stabilization with cement matrix etc. [11]. In like manner, fly ash produced during coal combustion in thermal power plants is one of the complex and abundant solid waste comprising major portion of $\mathrm{Si}$ and $\mathrm{Al}$ and small amounts of $\mathrm{Fe}, \mathrm{Ca}, \mathrm{Na}, \mathrm{P}, \mathrm{K}, \mathrm{Ti}$, and S. Fly ash are primarily in metal oxides forms which can easily agglomerate to form microspheres. Still another, Red mud produced during alumina generation from bauxite ores composed primarily of fine particles containing iron, aluminium, silicon, titanium oxides and hydroxides. Calcium is the main element of paper making industry with small number of other elements, including $\mathrm{Si}, \mathrm{Al}, \mathrm{Mg}, \mathrm{K}, \mathrm{Na}, \mathrm{Mn}$, and $\mathrm{Cr}[12]$.

Without proper treatment, the industrial waste can damage both environment and human. Conventional methods that are currently used for the treatment or disposal of industrial waste include landfill, incineration, curing and stabilization. However, all these technologies have certain disadvantages. For example, leakage of heavy metal and organics from the landfill potentially contaminates soil and groundwater; waste incineration reduces only the volume of waste polluting the air; high waste stabilization costs. According to the "3R" rules (Reduce, Reuse, and Recycle), it is urgently necessary to find a method for the utilization of industrial waste [13]. From a long term perspective, landfill is not environmentally benign method and may cause loss in huge amount of valuable resources and leaching of metals resulting serious secondary pollution. Thus the promising option for industrial waste treatment is to maximize the recovery and reusing of resource economically [14]. Many research works has been done to convert Industrial waste materials into valuable products such as ceramic [15], pigment [16-18], catalyst [14] etc. Recently it has gained interest in nanomaterial synthesis from waste and its application in pollutant removal due to its large surface area and properties. A survey of literature demonstrates that, this area is starting to attract more approach. The use of waste derived nanomaterials for the industrial application in pollution removal not only resolves the waste disposal problems but also helps in managing natural resource exploitation. Moreover, substituting the waste derived materials instead of virgin materials helps in improving the process economy, where the valuable materials are exploited in the production process. Therefore a great research interest is developing in usage of waste derived nanoparticle as an efficient and inexpensive material for the removal of pollutants from the environment. Previously, Yuan and Dai [19] has published a review paper which explains about the development of functional nanomaterials from sewage sludge and its applications. This review focuses on the nanomaterial synthesis from industrial waste streams highlighting the applicability of waste derived nanomaterial in pollution remediation.

\section{Recovery/Synthesis of Nanomaterial from Industrial Waste}

Conversion of regularly generated waste product into useful nanomaterial generally comes under the sustainable development [20]. A broad range of industrial waste has been thermo-chemically treated to recover valuable nanomaterials (Table 1). Different manu- facturing techniques have been employed for the synthesis of nanomaterial with various morphology and size. Conventional technologies use a top-down method for construction of materials, where bulk materials are broken into smaller pieces using mechanical, chemical or other forms of energy. On the other hand, in bottom-up approach the ions are chemically combined together to form the particles [21, 22]. Industrial waste derived nanomaterials synthesis technique by bottom up approach includes co-precipitation [23-27], hydrothermal method [17, 28-33], Microwave irradiation [34] and by top down approach include ball milling technique [35-39]. The metal and their oxides recovered from industrial wastes include $\mathrm{Cr}, \mathrm{Cu}, \mathrm{Fe}, \mathrm{Ni}, \mathrm{Ti}, \mathrm{Al}, \mathrm{Ni}$ and the nanomaterials have been regenerated from electroplating waste, picking waste, tannery waste, fly ash, steel industry waste, paper mill sludge, phosphogypsum waste etc. A few examples of recovered nanomaterials are $\mathrm{MFe}_{2} \mathrm{O}_{4}(\mathrm{M}: \mathrm{Mn}, \mathrm{Cu}, \mathrm{Zn}, \mathrm{Fe}, \mathrm{Ni}, \mathrm{Ag}$ ), magnetic biochar, magnetic chitosan, $\mathrm{TiO}_{2}$ modified fly ash and zeolite $[40,41]$

\subsection{Pre-treatment of Industrial Waste}

Industrial waste pre-treatment is a vital step for the production of nanomaterial from waste. Based on the composition of waste sample, preparation methods are categorized into physical treatment and chemical treatment methods. The chemical composition of the waste and the treatment method affect the physicochemical properties and surface functional group of synthesized nanomaterial. The process variables that has effect on synthesis include temperature, acid used for treatment and the chemicals used for activation [19, 42]. Initially industrial waste was directly used as catalyst without any pretreatment. The catalytic behaviour of Red mud and iron waste was studied for sulfadiazine degradation using $\mathrm{H}_{2} \mathrm{O}_{2}$ and persulfate with the generation of $\mathrm{OH}$ and $\mathrm{SO}_{4}{ }^{-}$. Then pretreatment of waste by physical and chemical activation was used to enhance the activity [12]. Ball milling of industrial waste is one of the physical treatment method which reduces the particle size to obtain homogenous mixture for further application [43, 44]. Lee et al. [45] studied the ball milling effect on particle size and its influence in calcium extraction from steelmaking slag. The finer the particle size, the reaction between the components becomes easier [46]. The efficiency of calcium extraction increased by ball milling effect (360 rpm for $72 \mathrm{~h}$ ) [11]. Subsequently, the basic aim of chemical pre-treatment is to remove any contaminants present in the waste sample that can be made soluble by heating or treating with chemicals. The presence of soluble salts such as chlorides, sulfates, and carbonates in the waste can cause defects because of their dissociation thereby damaging the products during firing at high temperatures. Abreu et al. [47] reported that the particle size distribution of waste influenced the salt extraction due to the demand of great quantities of water and long exposure time. Strong acid hydrolysis is a kind of chemical pre-treatment where concentrated strong acids (e.g., $\mathrm{HNO}_{3}, \mathrm{HCl}, \mathrm{H}_{2} \mathrm{SO}_{4}$ ) have been commonly applied for treating waste materials [48, 49]. For example, to prepare $\gamma$ - and $\alpha$-Al nanopowder from waste aluminum foils, waste materials were initially dissolved into aqua regia, after which an ammonia solution was added for maintaining the solution $\mathrm{pH}$ in the alkaline range [50]. 


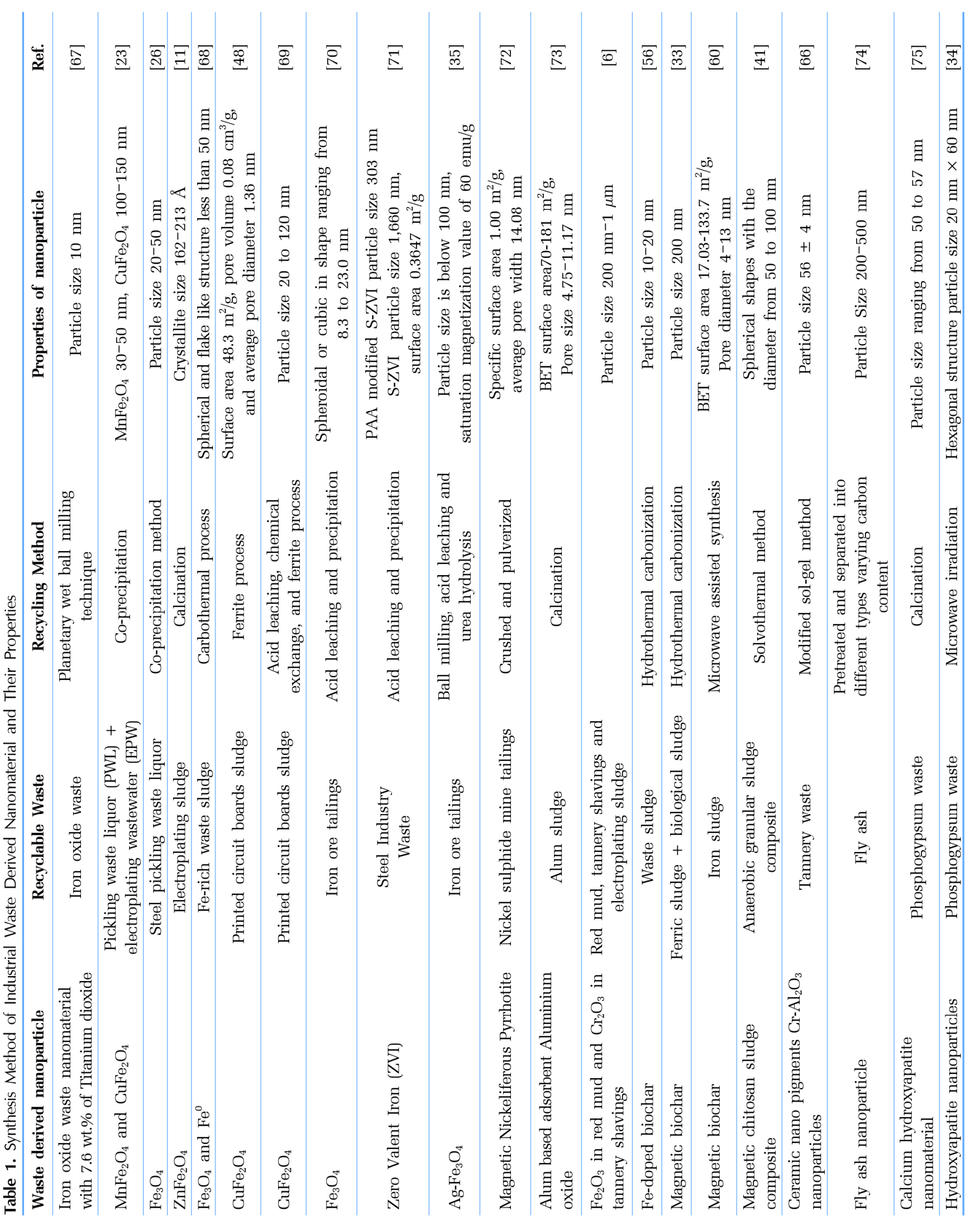




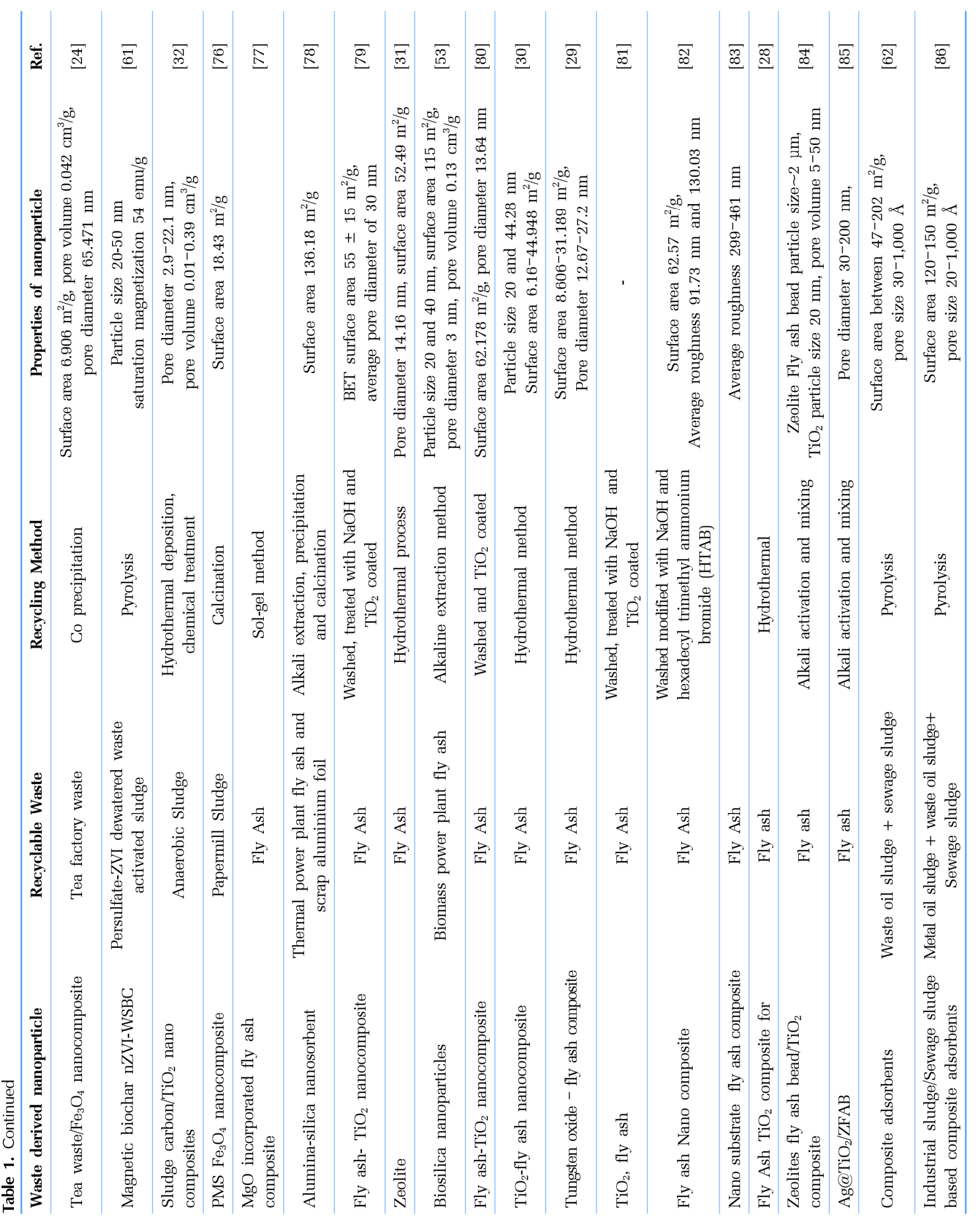




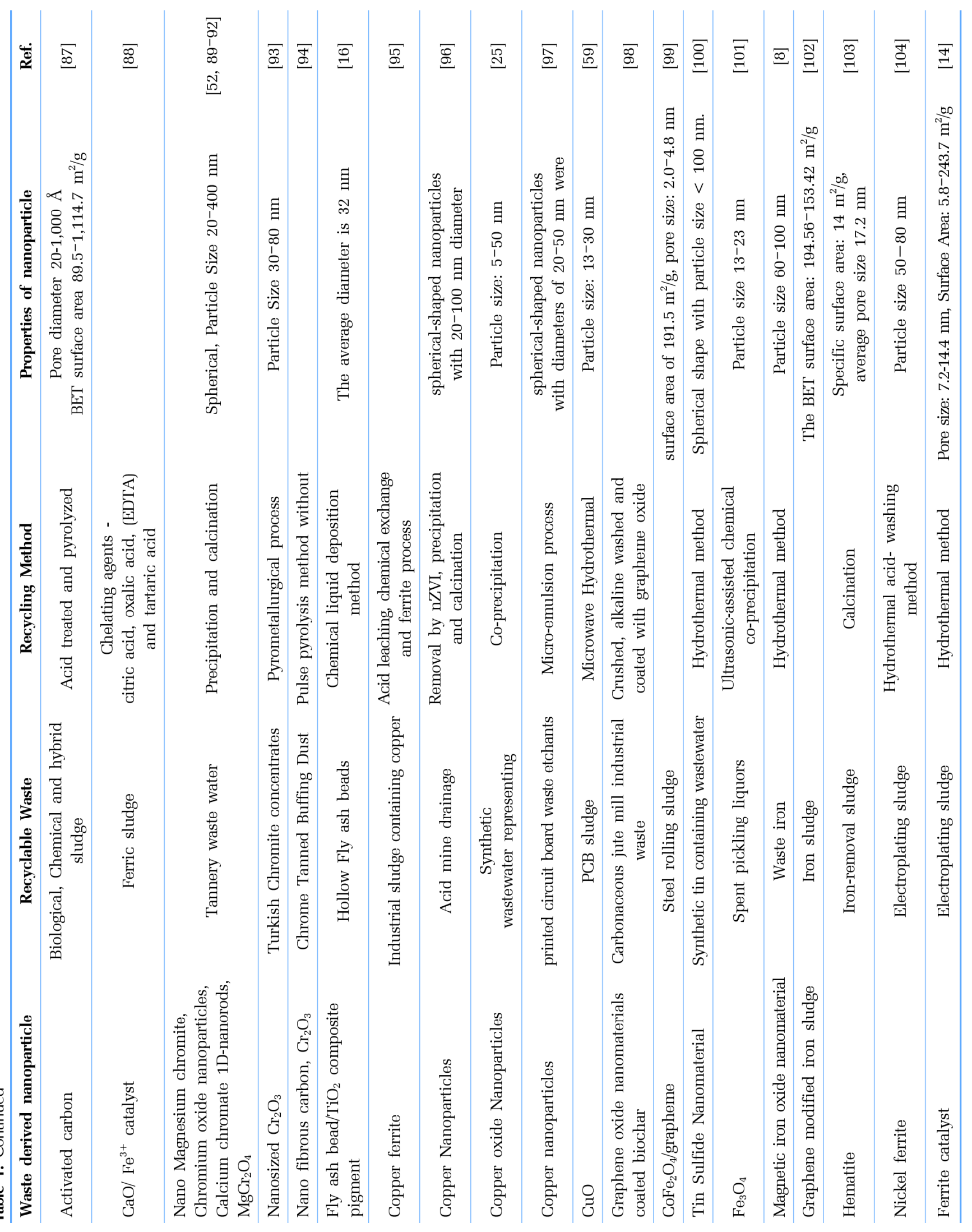




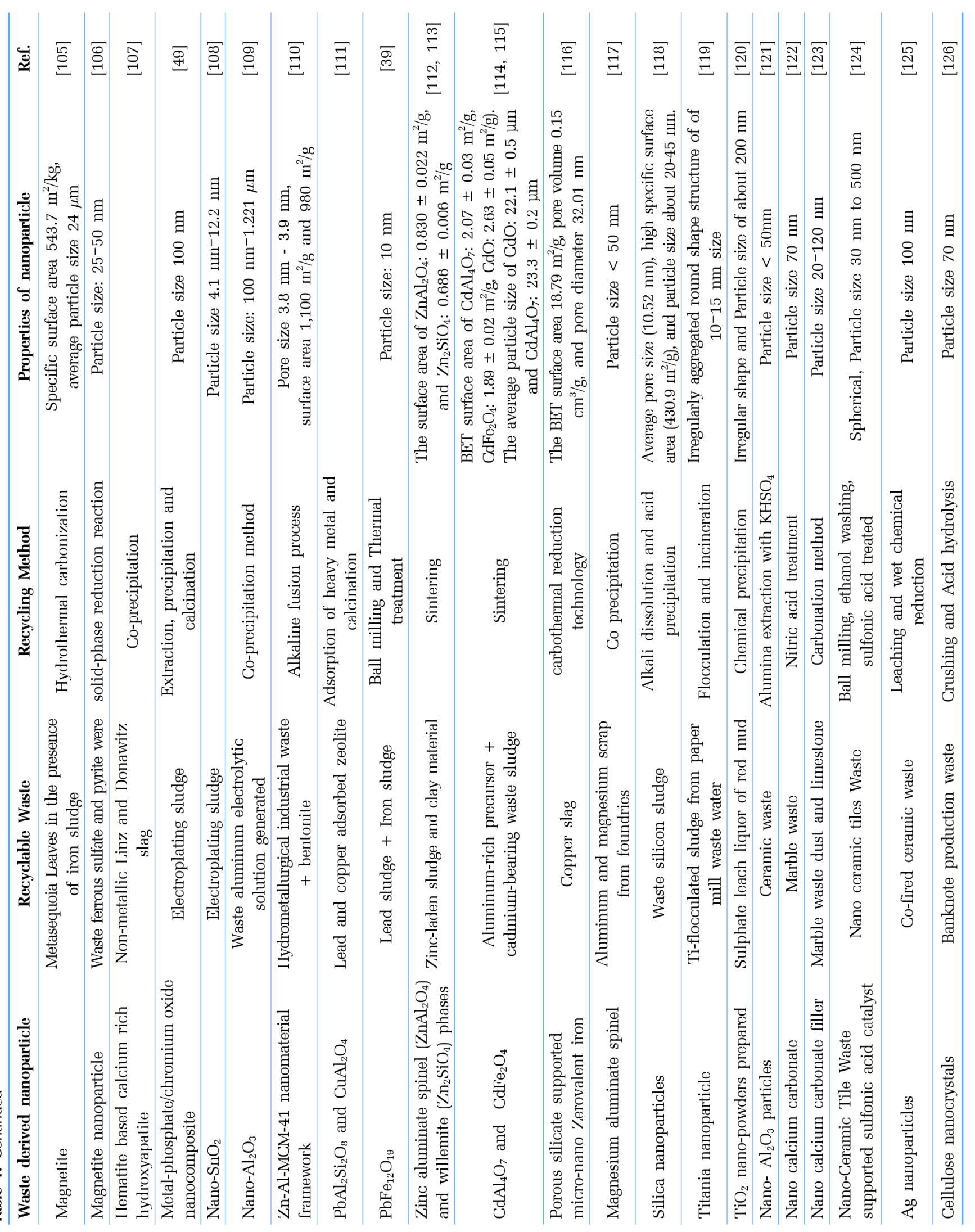




\subsection{Methods for Nanomaterial Synthesis}

Several thermo chemical methods can be used to synthesize industrial waste derived nanoparticles such as co-precipitation, hydrothermal, carbothermal, solvothermal and microwave assisted methods [21]. The synthesis of waste derived nanoparticles is a complex process because of their characteristics. For pollutant removal applications, surface modification of nanoparticles is considered as a critical aspect regarding both selectivity and aqueous stability [51]. A brief description of the most widely used methods for preparing nanomaterials with advantages and disadvantages are discussed below.

\subsubsection{Co-precipitation method}

Co-precipitation method is one of the most common wet chemical methods for obtaining waste derived nanoparticle. This method is widely used among other methods due to its simple operation and high yield of nanomaterials [12]. The metal content in the industrial waste was leached with acids $\left(\mathrm{HNO}_{3}, \mathrm{HCl}, \mathrm{H}_{2} \mathrm{SO}_{4}\right)$. The acid extracted metal solutions are treated with alkali $(\mathrm{NaOH}$, $\mathrm{MgO}$,) to increase the $\mathrm{pH}$ ranging from 7 to 12 [52]. The size and shape of the nanoparticle depends on the type of extractant, molar ratio of the metal, reaction temperature, $\mathrm{PH}$ and other reaction parameters, e.g., stirring rate, dropping speed of basic solution [23, 26, 27]. Liang et al. [53] synthesised silica nanoparticles by precipitating silica where, alkali extraction and acid treatment was done to bring up the $\mathrm{pH}$ to 7 and aging it for 12 $\mathrm{h}$ thereby dried at $100^{\circ} \mathrm{C}$. The purity of the nanoparticles obtained by precipitating silica from biomass flyash ranged from 44.42 to 93.63\%. The only disadvantage in precipitation method is, the products obtained seems to be less pure compared to the products obtained from other methods.

\subsubsection{Hydrothermal method}

Hydrothermal processing can convert waste to value added products by heating at high temperature $\left(120-550^{\circ} \mathrm{C}\right)$ and pressure $(20-150$ bar) with oxygen or an inert gas such as nitrogen. [54]. Solvothermal method is similar to hydrothermal method, but the only difference is in this method different solvents are used instead of water [55]. The materials prepared by this method contains many oxygen containing functional groups like $\mathrm{C}=\mathrm{O}, \mathrm{C}-\mathrm{O}$ and $\mathrm{O}-\mathrm{H}$ groups. Herein, $\mathrm{C}=\mathrm{O}$ could generate oxygen $\left({ }^{1} \mathrm{O}_{2}\right)$ species which degrades the organic pollutant by solving the environmental problem of carbon rich waste [56]. Ferrite catalyst from electroplating sludge [14], Mganetic biochar from ferric sludge and biological sludge [33], sludge carbon/ $\mathrm{TiO}_{2}$ nanocomposite from anaerobic sludge [32], $\mathrm{TiO}_{2}-\mathrm{FA}$ nanocomposites [30] and Tungsten oxide-FA nanocomposite [29] was prepared by hydrothermal method. It is considered to be an efficient method in treating wet solid waste rich in carbon, because it has more advantages than high temperature pyrolysis. The energy consumptions are low and the reaction conditions are mild and it has no requirement on the moisture content of the raw materials. So there is no need to dry the waste before hydrothermal treatment [56]. Importantly, the advantage of hydrothermal method is, it can be used to control material size, particle morphology, crystalline phase, and surface chemistry by controlling the reaction temperature, pressure and solvent properties and the main disadvantage is its high reaction temperature and pressure [55].

\subsubsection{Microwave assisted synthesis}

Microwave assisted synthesis method have been used in the synthesis of diverse inorganic materials such as metallic nanoparticles, amorphous and nanoporous materials, core-shell particles, semiconductors, bioceramics, pure and mixed metal oxides [57]. During synthesis process microwave energy strikes the material through molecular and ionic interaction of the precursor solvents and reducing agents [58]. Microwave radiation has also been used to detoxify sediment sludge and immobilization of metal ion within the sediment [59]. This method has many advantages over other techniques which includes, rapid heating, fast reaction, high yield and excellent thermal stability thus being one of the most effective method for nanoparticle synthesis [34]. Duan et al. [60] synthesized magnetic biochar from iron sludge and cotton stalk for the removal of $\mathrm{Cr}(\mathrm{VI})$ using microwave chemical reactor. Zhang et al. [34] successfully synthesized hydroxyapatite nanoparticles from phosphogypsum waste produced from phosphorus fertilizer factory and checked its application for fluoride removal from aqueous solution. This method is upright compared to other synthesis methods due to their low temperature operation and its quick method of producing crystalline nanomaterials [55].

\subsubsection{Pyrolysis}

Pyrolysis is one of the most effective methods which helps to produce materials with satisfactory surface area, stable structure, great ion exchange capacity and value added surface functional groups like $-\mathrm{OH},-\mathrm{COOH}, \mathrm{C}-\mathrm{O} / \mathrm{C}=\mathrm{O}$ [61]. Pyrolysis temperature and reaction time plays a major role in altering the surface chemistry of the material. It affects the surface affinity to adsorb water, which proves to be an important factor in adsorption reaction. In a study conducted by Bandosz [62], temperature increase from 650 to $950^{\circ} \mathrm{C}$ resulted in increase of surface $\mathrm{pH}$. Thus, the surface properties, such as porosity, selectivity, or catalytic activity can be modified by changing the pyrolysis conditions. The catalytic activity of the product is directly related to the new surface chemistry formed by solid-state reactions during pyrolysis. The disadvantages of this method are release of toxic gas release during material synthesis process and high energy consumption [12].

\subsubsection{Sol-Gel method}

Sol-gel method is in existence since 1800s and is applied in the development of materials for catalysis, chemical sensors, membranes, fibres and used in scientific and engineering fields. In this technique, a colloidal suspension is formed from the precursors by hydrolysis, polycondensation, aging, drying and thermal decomposition. The materials synthesized by Sol-gel method were highly crystalline with smaller crystallite size when compared to materials prepared by hydrothermal method under similar reaction conditions [63, 64]. Inorganic metal salts or metal organic compounds are the mostly used precursors in this method. Concerning the gel formation, the factors that impact the properties include solvent type, water content, acid or base content, precursor concentration and temperature [55]. The most important advantage of this method is that, the nanomaterial with high surface area and stable surfaces are formed at the end of the process [65]. As in, single phase chromium doped $\alpha$-alumina nanoparticles was synthesized using sol-gel method by recycling chromium containing tannery waste using an initial 
solution $\mathrm{pH}$ of 4.0 and calcined at $1,100^{\circ} \mathrm{C}$ [66]. Similarly, coral like hierarchical magnesium oxide incorporated fly ash composite is formed by agglomeration by sol-gel method and is used as an adsorbant for Reactive Black 5 azo dye from aqueous solution.

\subsubsection{Calcination}

Calcination is done for the structural transformation of waste, which focuses on final product of oxide and mixed oxide. When the calcination temperature is below $400^{\circ} \mathrm{C}$, the simple metal oxide was formed. However, at calcination temperature higher than $600^{\circ} \mathrm{C}$ spinel oxide was formed. By controlling the calcination temperature interesting functional materials were potentially obtained. When the precursor is calcined at lower temperature it gets transformed into layered double hydroxide. And, when this product was immersed in water or placed in moist gas, it reconstructed and the process is called "memory effect." Conversely, if the calcination temperature was too high, the spinel will become unrecoverable [13].

\section{Application for Pollutant Remediation}

Different types of nanocatalysts such as semiconductors and metal oxides are used for wastewater treatment herein the photocatalysts, electrocatalysts and Fenton-based catalysts are used to improve chemical oxidation of organic pollutants and antimicrobial actions [127]. Recently various research was carried out for the removal of organic and inorganic contaminants by the nanomaterials obtained through processing of industrial waste. In this part the application of industrial waste derived nanomaterial for pollutant remediation is discussed. Table 2 summarizes the method of removal of pollutant and their removal capacities using industrial waste based nanomaterial.

\subsection{Heterogeneous Phototcatalytic Degradation}

Heterogeneous photocatalysis is recognized as a very potential technology for the removal of organic contaminants from water [128]. Heterogeneous photocatalysis takes place on the surface of catalyst and the pre-adsorption of pollutants are essential for their degradation. This is attained by using large surface area supports for adsorption and high adsorption capacity for target material. Adsorption strength of the substrate should be fair enough for its diffusion into the loaded $\mathrm{TiO}_{2}$. Many support materials such as activated carbon, stainless steel, silica, zeolites or clay materials were used to prepare hybrid photocatalysts [129]. Recently, utilization of waste material as surface support of $\mathrm{TiO}_{2}$ based photocatalyst has paid attention.

\subsubsection{Photocatalytic activity of Fly ash/ $/ \mathrm{TiO}_{2}$ nanocomposites}

Fly ash serves as adsorption substrate along with $\mathrm{TiO}_{2}$ photocatalyst which represents an efficient and environmental friendly solution. The nanocomposites simultaneously removes two pollutants with different chemical structure and is accounted for the treatment of wastewaters loaded with heavy metals, dyes and surfactants [28, 127]. Fly ash is a mixture of unburned carbon and metal oxides in which $\mathrm{Fe}_{2} \mathrm{O}_{3}$ and $\mathrm{MnO}$ can act as in situ Fenton-systems and $\mathrm{TiO}_{2}$ being likely active in photocatalysis. Waste fly ash are promising support materials because of their surface composition,

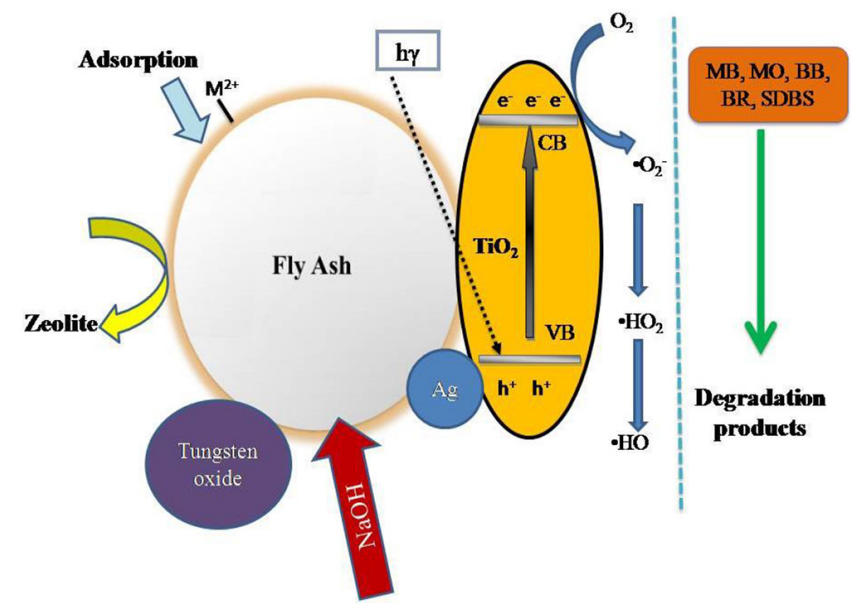

Fig. 1. Schematic diagram of the Fly ash/ $/ \mathrm{TiO}_{2}$ nanocomposites and the mechanism of photo-degradation and adsorption.

charge and morphology [80]. The photo-degradation and adsorption of Methylene blue, Bemacid Blau and Bemacid Rot, surfactant SDBS, $\mathrm{Cd}$ and $\mathrm{Cu}$ by Fly ash/TiO2 nanocomposites was extensively studied by Visa et al. [30, 79, 80, 82] The alkali activation can develop new active site ( $\left.\equiv \mathrm{SiO}^{-}\right)$and ( $\equiv \mathrm{AlO}^{-}$) on FA surface which allows metals to be complexes at the surface. The change in chemical and structural property induce surface modification resulting in difference in surface affinity for $\mathrm{Cd}^{2+}$ and $\mathrm{Cu}^{2+}$ before and after treating with $2 \mathrm{~N} \mathrm{NaOH}$ [81]. Yang et al. [84] investigated the degradation effeciency of Rhodamine $\mathrm{B}$ by Zeolites fly ash bead $(\mathrm{ZFAB}) / \mathrm{TiO}_{2}$ composite and benzene by $\mathrm{Ag} @ \mathrm{TiO}_{2} / \mathrm{ZFAB}$. The composite was prepared by alkali activation by $\mathrm{NaOH}$ and mixing with $\mathrm{TiO}_{2}$ nanomaterial. The degradation efficiency of $\mathrm{RhB}$ dye reaches $83.8 \%$ after five cycles. This indicates that the prepared material has a good recyclability for $\mathrm{RhB}$ degradation. The removal rate of benzene gas reached 96.3\% after three cycles, indicating the $\mathrm{Ag} @ \mathrm{TiO}_{2} / \mathrm{ZFAB}$ modified photocatalytic cementitious material exhibits constancy.

\subsubsection{Photocatalytic activity of other nanocomposites}

Photocatalytic mechanism involves the generation of electron hole pairs upon irradiation of light which results in the formation of oxidizing and reducing agents on the surface of semiconductors. These oxidizing and reducing agents favour the degradation of organic pollutants in the presence of photons. Several semiconductor metal oxide photocatalysts including $\mathrm{CdO}-\mathrm{SnO}_{2}$, $\mathrm{ZnO}-\mathrm{Cu}_{2} \mathrm{O}, \mathrm{Cu}_{2} \mathrm{O} / \mathrm{TiO}_{2}, \mathrm{SnO}_{2}-\mathrm{TiO}_{2}, \mathrm{SnO}_{2}$-Graphene, $\mathrm{SnS}_{2}-\mathrm{SnO}_{2}$, $\mathrm{TiO}_{2} / \mathrm{CuS}, \mathrm{NaNbO}_{3} / \mathrm{CdS}$ etc., have been developed, which can extend the absorption range to the visible region thereby suppressing the recombination of electron-hole pairs to improve the photocatalytic efficiency of the photocatalyst [132]. The zeta potential value of Magnetic iron oxide nanomaterial derived from industrial waste was positively charged at $\mathrm{pH} 2$ and 3 and negatively charged from $\mathrm{pH} 5$ to 10 . The catalyst surface adsorbed $\mathrm{H}^{+}$ions in the acidic medium and the basic medium due to the presence of $\mathrm{OH}^{-}$ ion thus two anionic dye (Methylene blue and Congo Red) and cationic dye (Rhodamine B) were degraded. The photocatalytic degradation of magnetic iron oxide nanopowder showed a better recyclable capacity of $78 \%$ upto 10 cycles [67] 


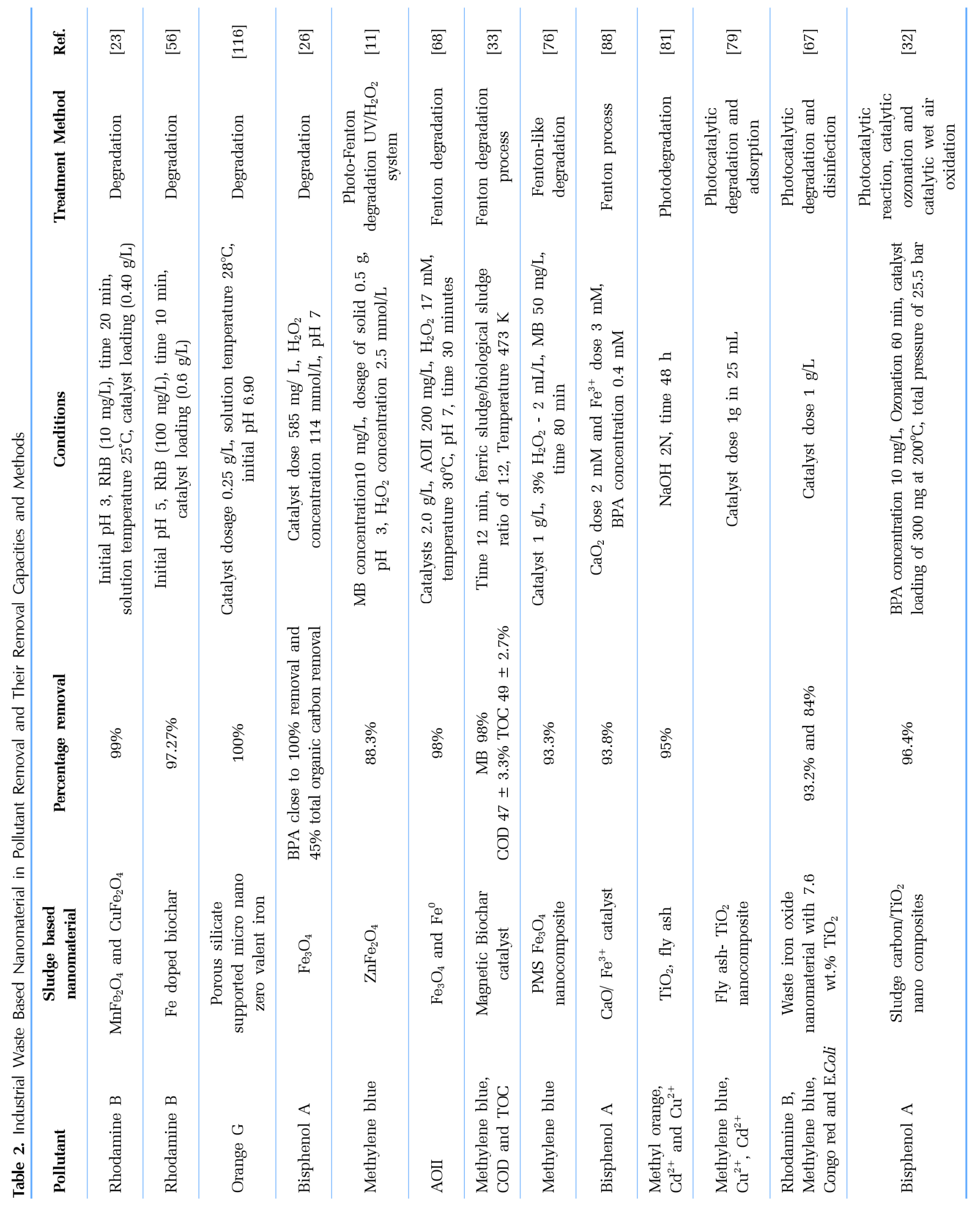




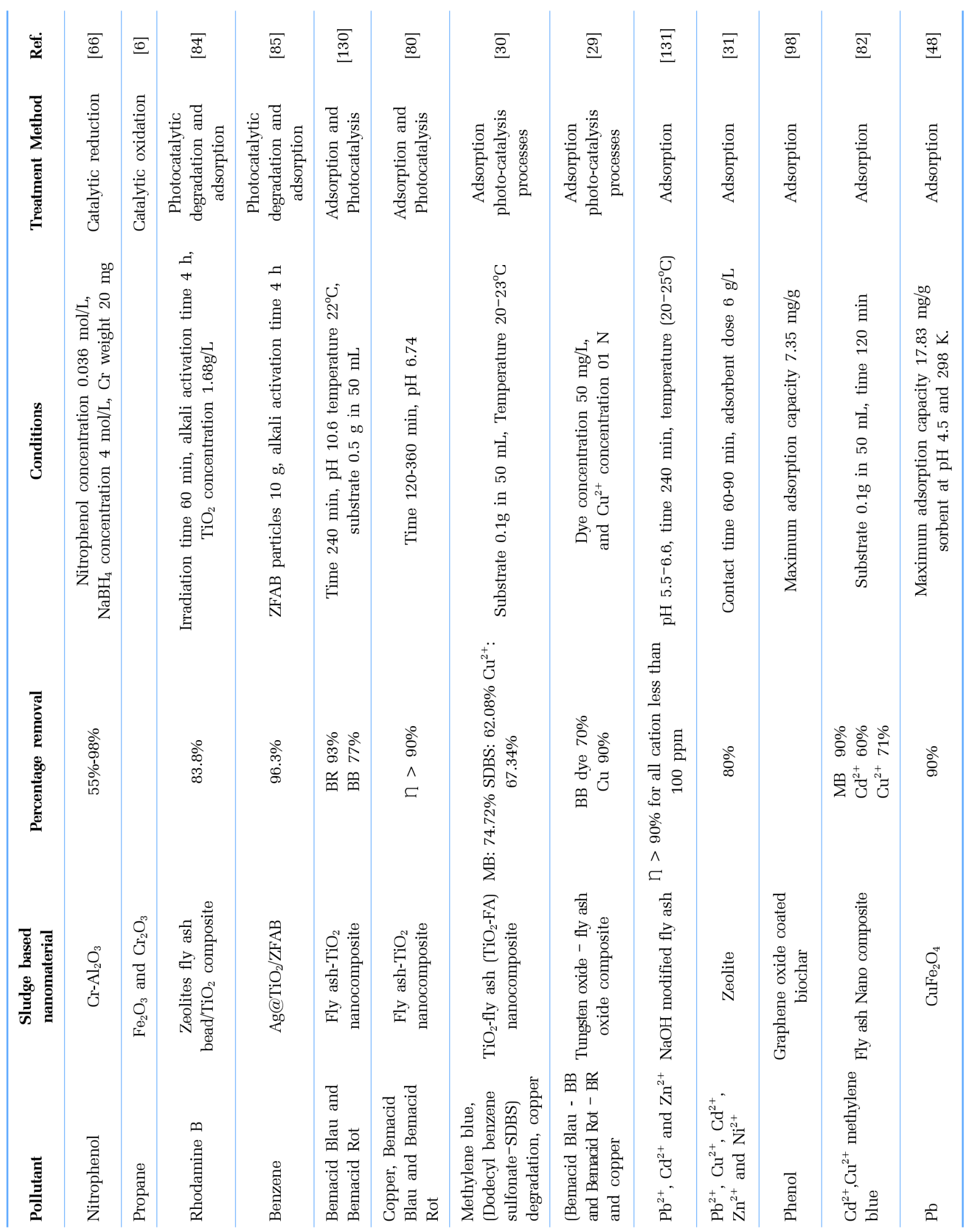




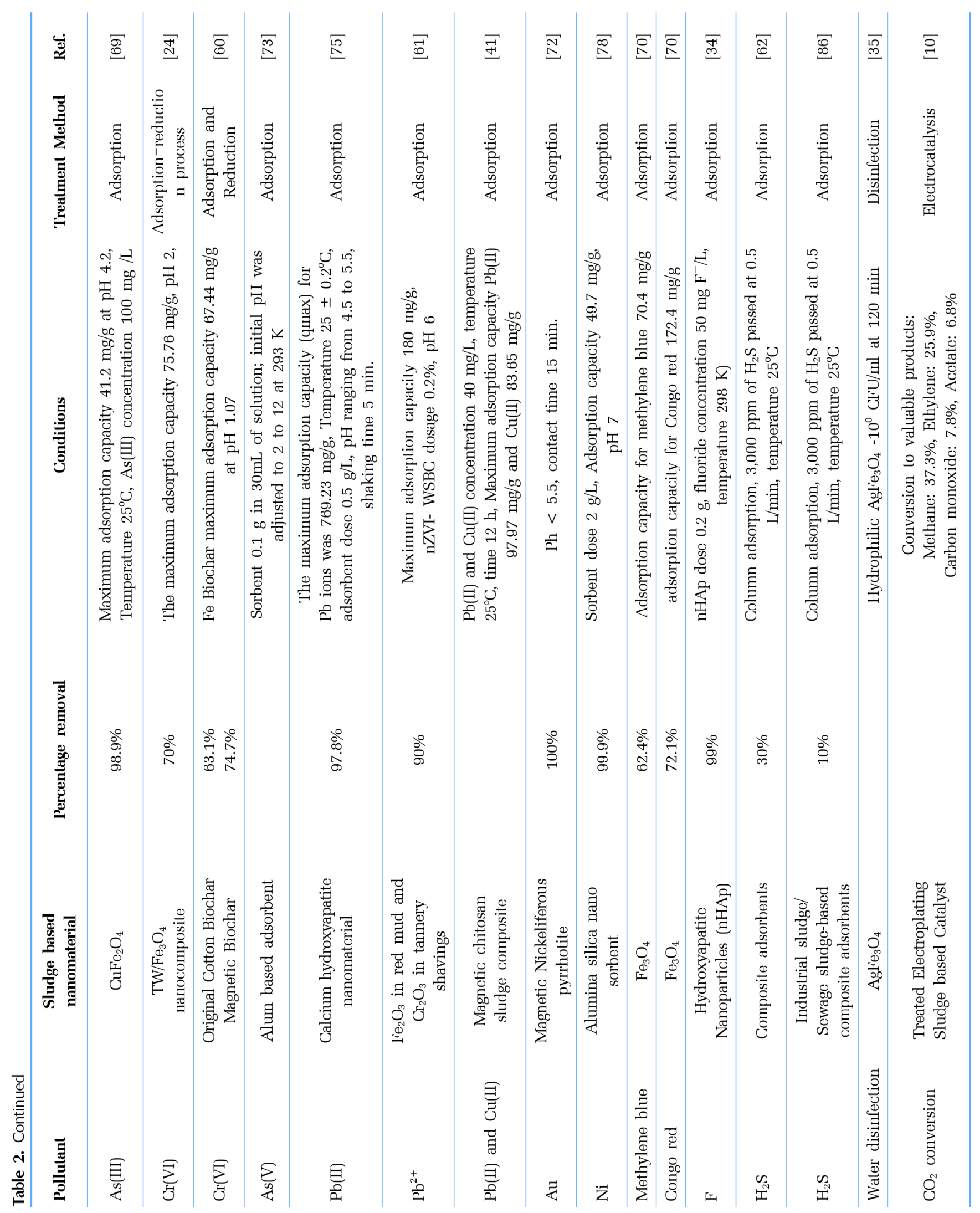


Tungsten oxide $\left(\mathrm{WO}_{3}\right)$, a semiconductor photocatalyst with 2.8 $\mathrm{eV}$ band gap, is activated by a portion of the visible light irradiation $(\lambda<442 \mathrm{~nm})$. It has drawn interest as an alternative for $\mathrm{TiO}_{2}$. The tandem's concept could be extended by mixing $\mathrm{WO}_{3}$ with other semiconductors, with suitably aligned band gap. As fly ash (FA) contains traces of a $\mathrm{TiO}_{2}$, it is used as photocatayst along with Fenton precursors $\left(\mathrm{Fe}_{2} \mathrm{O}_{3}, \mathrm{MnO}\right)$ which can participate in the hydroxyl generation process. Visa et.al., explored novel composite based on tungsten oxide and fly ash by hydrothermal synthesis and used as a substrate to treat Bemacid Blau - BB and Bemacid Rot $-\mathrm{BR}$ dye and $\mathrm{Cu}^{2+}$ heavy metal ion [29]. Zeolites fly ash bead/ $/ \mathrm{TO}_{2}$ composite was prepared by Alkali activation and mixing with $\mathrm{TiO}_{2}$ and is used for Rhodamine B dye degradation [84]. Additionally, Carbon based nanomaterial prepared from anaerobic sludge impregnated with $\mathrm{TiO}_{2}$ serves as a catalyst to degrade Bisphenol A. $\mathrm{TiO}_{2}$ addition on the surface of sludge carbon increase the mobility of charges, electro negativity and electro affinities, which in turn enhances photocatalytic activity [32].

\subsection{Heterogeneous Fenton and Photo-Fenton Degradation}

Fenton's reagent is a mixture of ferrous ions and hydrogen peroxide $\left(\mathrm{H}_{2} \mathrm{O}_{2}\right)$, which forms active oxygen species capable of oxidizing organic contaminants. Photo-Fenton process combines the effect of the Fenton's reaction and UV-Vis to produce hydroxyl radicals along with the photo-reduction of the ferric ions to form ferrous ions, which in turn contribute to the Fenton's reaction. This creates more hydroxyl radicals compared to the classical Fenton and hence accelerates the oxidation process, which is considered as an advantage of this process [133].

Hydrothermal synthesis of Ferric sludge and biological sludge derived from the dyeing wastewater treatment process yielded magnetic biochar and degradation efficiency Methylene blue was catalyzed by Fenton process (Fig. 2). Dyeing wastewater was treated with Magnetic biochar, removal efficiency of Methylene blue was $98 \%$ and the catalytic efficiency was stable upto $4^{\text {th }}$ cycle. The COD removal rate was $47 \pm 3.3 \%$ and TOC removal was observed to be $49 \pm 2.7 \%$ [33]. Previously Zhou at al. [76] synthesized magnetic biochar, a heterogeneous catalyst derived from paper mill sludge for the Fenton-like degradation of methylene blue with $93.3 \%$ removal efficiency. For the degradation of Bisphenol A, ferric sludge was used as catalyst source along with calcium peroxide and the ability of chelating agents, such as citric acid, oxalic acid, ethylene diamine tetra acetic acid and tartaric acid to hasten the BPA degradation and to reduce the $\mathrm{Fe}^{3+}$ dosage was assessed [88]. Meanwhile, Kong et al. [68] reported the conversion of iron rich sludge into Fe-SC hybrid Fenton-like catalyst by carbothermal process for the degradation of AOII. The efficiency AOII degradation achieved within $20 \mathrm{~min}$ at $30^{\circ} \mathrm{C}$ temperature and $\mathrm{pH}$ 7. Magnetic separable $\mathrm{MnFe}_{2} \mathrm{O}_{4}$ nanoparticle and $\mathrm{CuFe}_{2} \mathrm{O}_{4}$ was obtained from synthesised by co precipitation of heavy metal containing pickling waste liquor (PWL) and electroplating wastewater (EPW). The fenton like degradation of Rhodamine B removed up to $99 \%$ of dye and remained unchanged upto 8 cycles [23]. Similarly, Huang et al. [26] reported removal fenton like degradation of Bisphenol A, close to $100 \%$ and TOC $45 \%$, by $\mathrm{Fe}_{3} \mathrm{O}_{4}$ nanoparticles from steel pickling waste liquor.

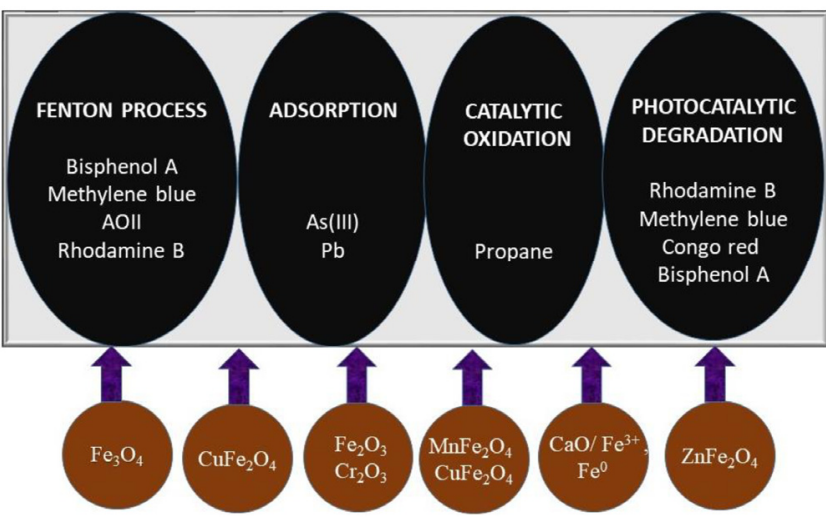

Fig. 2. Schematic representation of iron waste derived catalyst and its application in pollutant remediation.

A zinc ferrite catalyst was prepared by the calcination of electroplating sludge (ES) for efficient degradation of methylene blue. The catalyst displayed $88.3 \%$ decolourization efficiency of methylene blue in the presence of $\mathrm{H}_{2} \mathrm{O}_{2}$ combined with UV irradiation. The small amount $\mathrm{Al}$ and $\mathrm{Mg}$ present in the sludge might also contribute to the catalysis[11]. The ferrite based fenton catalyst synthesized from industrial waste proves to be efficient in removing dye from wastewater and stable after recycling.

\subsection{Catalytic Degradation}

Waste as raw material for the synthesis of catalyst has gained interest due to the demand of catalyst in various industrial sectors. Catalytic reduction of 4-nitrophenol to aminophenols is investigated in the study conducted by Cunha et al. [66]. The chromium waste from tannery industry is doped with Alumina to synthesize catalyst to reduce 4-nitrophenol to aminophenols, which has wide application in the synthesis of industrial dyes, pharmaceuticals, and other biologically active compounds. The kinetics of the catalytic reduction of 4-nitrophenol was very fast, varying from $45 \mathrm{~s}$ to $40 \mathrm{~min}$ that are strongly influenced by the concentration of chromium ions in the $\alpha$-alumina matrix. The efficiency of the recycled wastes in reducing 4-nitrophenol was dependent on their purity, with the conversion rates for the wastes varying from $55 \%$ to $98 \%$. The catalytic capacity of waste derived catalyst is similar to those reported for high-purity catalyst [66]. Recently Sulfate radicals and hydroxyl radicals are commonly used as oxidizing agents for degradation of organic compounds. Usually, $\mathrm{SO}_{4}{ }^{-}$are produced by the activation of peroxymonosulfate (PMS). Zhang et al. [56] fabricated sludge-based biochar material doped with $\mathrm{Fe}_{3} \mathrm{O}_{4}$ by hydrothermal carbonization and activated by peroxymonosulfate for degradation of Rhodamine B of 50 ppm in 10 min. Catalytic oxidation of Volatile organic compound employing propane as a model gas was explored by Sushil et al. [6]. Wastes from the aluminium industry, the tannery industry and the electroplating industry were tested as precursors for catalysts. The quantity of ferrite in red mud and chromite in tannery shavings governs in determining the catalytic reduction of propane. By adding chromium containing waste to red mud, the catalytic activity increased. A 50\% conversion of propane was achieved in the range $320-380^{\circ} \mathrm{C}$. Much less studies were reported that deals with the catalytic conversion by pollutants 
by utilizing waste derived materials as catalyst.

\subsection{Electrocatalysis}

Electrocatalysis is accompanied by charge transfer processes that play important role in sustainable development and technological advancement. The major electrochemical processes include, electrochemical reduction of $\mathrm{CO}_{2}$ into synthetic liquid fuels, water splitting to generate molecular hydrogen from water, energy recovery in fuel cells and solar cells. The development of nanomaterials for electrocatalysis is a vibrant research field [134]. Waste containing high organic content as well as low content of metals is generally used to synthesize electrocatalyst, since metal dopant played an important role in enhancing electrocatalytic activity. The sludge with complex organics are possibly used as a low cost precursor to synthesize electrocatalysts for $\mathrm{H}_{2} \mathrm{O}_{2}$ generation. Using high organic content porous carbon electrode was formed. The components present in waste such as $\mathrm{N}, \mathrm{S}$ and $\mathrm{P}$ are transformed to heteroatoms on the electrode surface [13]. The performance of electrocatalysts and its efficiency depend upon its structure, components and surface characteristics, which depend on the method of synthesis. Catalyst derived from thermally treated electroplating sludge is used in the electrochemical reduction of $\mathrm{CO}_{2}$ with a peak potential of -0.3 $\mathrm{V}$, as measured using a linear sweep voltammogram proves to pocess good electrocatalytic activity. Additionally, it is used in a microbial electrolysis cell in converting $\mathrm{CO}_{2}$ to methane, ethylene, carbon monoxide and acetate with faraday efficiencies of $37.3 \%, 25.9 \%$, $7.8 \%$ and $6.8 \%$ at an external potential of $0.6 \mathrm{~V}$, respectively [10].

\subsection{Adsorption of Pollutant}

Pollution was recognized as one of the significant threat to humankind; in this manner an ever increasing number of examinations are committed to executing the idea of expelling waste by utilizing squanders [130]. To avoid the environmental pollution many methods were developed for removing contaminants. Adsorption is widely considered to be an important physicochemical process and its practical application relies upon recovering and reusing the spent adsorbents [135]. Non-conventional adsorbents usage is getting importance and several low cost materials including wood dust, neem bark, rice bran, leaf dust, agricultural wastes, biological wastes, clarified sludge, flyash, kaolinite clay and zeolite are used [78]. Utilization of waste as an adsorbent to remove the pollutants from the environment has gained interest in recent years. It has gained much attention because it simultaneously solves two problems: pollutant removal and application of waste as adsorbent [79]. Nano-sized particles are attracting considerable interest as adsorbent due to their high surface area and thus enhancing the adsorption of pollutant on their surface [136]. Many researches have been carried out to remove heavy metal and dyes using industrial waste derived nanomaterials as an adsorbent. Removal of $\mathrm{Cr}(\mathrm{VI})$ by tea waste/ $\mathrm{Fe}_{3} \mathrm{O}_{4}$ nanocomposite [24] and $\mathrm{Fe}$ loaded magnetic biochar [60], $\mathrm{As}(\mathrm{V})$ removal by alum based adsorbent [73], $\mathrm{Pb}(\mathrm{II})$ removal by Calcium hydroxyapatite nanomaterial [75] and $\mathrm{Fe}_{2} \mathrm{O}_{3}$ in red mud and $\mathrm{Cr}_{2} \mathrm{O}_{3}$ in tannery shavings [61], $\mathrm{Pb}$ (II) and $\mathrm{Cu}$ (II) removal by Magnetic chitosan sludge composite [41] Methylene blue and Congo red removal by $\mathrm{Fe}_{3} \mathrm{O}_{4}$ [70], $\mathrm{F}$ removal by Hydroxyapatite Nanoparticles (nHAp) [34] and H2S removal by sludge based nano- composite $[62,86]$. Steel slag has potential to adsorb Ni(II) from aqueous solutions due to its high concentration of magnetite and its adsorption rate increased with initial concentration but decreased with increase in temperature, due to competition by other ions dissolved from steel slag [127].

The adsorption mechanism of pollutants on the nanocomposite denotes to physical adsorption, electrostatic interaction, reduction, ion exchange, surface complexation, etc. Tu et al. [48] studied the adsorption behaviour of $\mathrm{As}(\mathrm{III})$ and $\mathrm{Pb}$ on to copper ferrite nanomaterial synthesized from the sludge of printed circuit board (PCB) industry. He found that higher the $\mathrm{pH}$ value decreased the adsorption capacity of copper ferrite due to enhanced repulsion between As(III) and the adsorbent surface [48, 69]. Manna et al. [98] synthesized graphene oxide coated over pre-treated carbonaceous industrial for the separation of phenol which sowed better separation performance than that of the graphene oxide. Similarly, meso-macropore adsorbents were prepared from hybrid of biological sludge and chemical sludge that showed higher adsorption than that of the commercial activated carbon due to the well-developed mesopore and macropore structure, as well as abundant acidic surface functional groups [87]. While, Cation adsorption involves mainly electrostatic forces therefore the surface energy of the substrate strongly influences the adsorption process [131]. The $\mathrm{pH}$ is one of important parameter which significantly affect the adsorption capacity by influencing (1) the surface charge of the adsorbent, (2) the degree of ionization of the adsorbate and (3) extent of dissociation of functional groups [70]. The maximum adsorption capacity of As(III) was found to be $41.2 \mathrm{mg} / \mathrm{g}$ at $\mathrm{pH} 4.2$, much higher than most of the adsorbents. Subsequently, over $90 \%$ of lead was removed at $\mathrm{pH} 4.5$ using copper ferrite nanoparticle [48, 69]. Visa, 2016 investigated zeolite as adsorbents for the simultaneous removal of heavy metals $\left(\mathrm{Cd}^{2+}, \mathrm{Cu}^{2+}, \mathrm{Ni}^{2+}, \mathrm{Zn}^{2+}\right.$ and $\left.\mathrm{Pb}^{2+}\right)$. The increase in the substrate amount creates more active centres favourable for adsorption of heavy metals. New active centres (三 SiO-) and ( $\equiv$ AlO-) has developed on zeolite surface forming complex structures with metal cations thereby replacing the exchangeable $\mathrm{Na}^{+}, \mathrm{K}^{+}$ cations [31]. Increased ion exchange capacity was observed by S.Fan et al. [24] when the $\mathrm{Cr}(\mathrm{VI})$ was removed by the Tea Waste/ $/ \mathrm{Fe}_{3} \mathrm{O}_{4}$ nanocomposite.

\subsection{Disinfection Using Industrial Waste Derived Nanomaterial}

Antibacterial agents are compounds that kill bacteria or slow down their growth and have been used in many fields, such as, textile industry, water disinfection, food packaging, and medicine [137]. Antibacterial activity of $\mathrm{Ag}-\mathrm{Fe}_{3} \mathrm{O}_{4}$ nanoparticle synthesized from iron ore tailing was carried out by using spot inoculation method using Escherichia coli, a gram-negative bacterium cultured in agar media and compared with $\mathrm{Fe}_{3} \mathrm{O}_{4}$, hydrophobic and hydrophilic $\mathrm{Ag}-\mathrm{Fe}_{3} \mathrm{O}_{4}$ nanomaterials. The result revels that $\mathrm{Fe}_{3} \mathrm{O}_{4}$ does not show any zone of inhibition area whereas hydrophobic and hydrophilic $\mathrm{Ag}-\mathrm{Fe}_{3} \mathrm{O}_{4}$ exhibit significant zone of inhibition area from 60-120 minutes confirming the role of Ag. Silver and its compounds are shown to be effective against both aerobic and anaerobic bacteria by precipitating bacterial cellular proteins and by blocking the microbial respiratory chain system. Hence, magnetite nanoparticles derived from iron ore tailings can act as a good support for silver 
nanoparticles to use it effectively in the water disinfection [35] Similarly, Boruah et al. [67] studied about the inactivation of biological contaminants by photocatalytic method under irradiation of natural sunlight in an aqueous medium. Magnetic mixed metal oxide nanomaterial synthesized from industrial waste showed $96 \%$ inactivation of E.coli bacteria within $120 \mathrm{~min}$ at $\mathrm{pH} 5$ with the catalytic loading rate of $1 \mathrm{~g} / \mathrm{L}$ and E.coli concentration $200 \mathrm{mg} / \mathrm{L}$.

$$
\begin{gathered}
\text { Cell membrane }+\cdot \mathrm{OH} \rightarrow \\
\text { Liquid peroxidation (Membrane distraction) } \\
\text { Exposed cellular constituents } \rightarrow \\
\text { degradation products }
\end{gathered}
$$

The above equation explains the inactivation mechanism, where, - $\mathrm{OH}$ formed during the reaction acts as an oxidizing agent. Hydroxyl radical is responsible for the oxidation of polyunsaturated phospholipids as well as destruction of bacterial cell membrane resulting cell death [67].

\section{Conclusions and Recommendations}

The increasing generation of industrial waste has forced the researchers to work on effective utilization of waste to achieve the concept of treatment of waste and wealth from waste. As nanotechnology is the fast growing field and by considering its applications in various field, nanomaterial synthesis from waste is considered to be an effective way which offers valuable recovery of elements and economic advantages. However, to solve the problem arising due to increased generation of waste and exploitation of primary resources research needs to be done to improve and develop the recovery process. Industrial waste such as Tannery waste, electroplating industry waste, papermill waste, steel industry waste, fly ash, jute mill industrial waste, silicon waste etc., have been utilized in synthesizing waste derived nanomaterials and each method of synthesis has its own advantage. More specifically, the pretreatment of waste influences the properties of the nanomataerial by affecting the surface chemistry. It is clear that the physical and chemical factors during synthesis process affect the formation of nanomaterial. Therefore, the practicability of synthesis methods, for large scale production of waste derived materials should be taken in to consideration. Specifically, further studies needs to be carried to manage the toxic gases that are released during the thermal synthesis method. The waste derived nanomaterial synthesized by physico chemical methods have wide application in environmental remediation. The nanomaterials synthesized from industrial waste include $\mathrm{Fe}_{3} \mathrm{O}_{4}, \mathrm{MFe}_{2} \mathrm{O}_{4}$ (M- Mn, $\mathrm{Cu}, \mathrm{Zn}, \mathrm{Ag}$ ), magnetic biochar, $\mathrm{MgCr}_{2} \mathrm{O}_{4}, \mathrm{Cr}_{2} \mathrm{O}_{3}$, $\mathrm{CuO}$, Copper ferrite, etc., Among which iron rich waste is widely used and has been proven to be effective in removal of pollutant by fenton degradation, photocatalytic degradation and adsorption method. Despite the application in pollutant remediation, it is important to study the hazard that may cause by the by-products during reaction or leaching back of original pollutants. However, for further large application of waste derived nanomaterials, LCA needs to be done by focusing on energy consumption, pollution reduction and cost efficiency. Additionally, by increasing stability and activity of the nanomaterials, sustainable zero waste can be achieved.

\section{Author Contributions}

J.V.J. (Research Scholar) wrote the manuscript. N.V. (Professor) revised the manuscript.

\section{Reference}

1. Zhang T, Gao PP, Gao PP, Wei J, Yu Q. Effectiveness of novel and traditional methods to incorporate industrial wastes in cementitious materials - An overview. Resour. Conserv. Recycl. 2013;74:134-143.

2. Tang Y, Chan SW, Shih K. Copper stabilization in beneficial use of waterworks sludge and copper-laden electroplating sludge for ceramic materials. Waste Manag. 2014;34:1085-1091.

3. Schwarz M, Veverka M, Michalkova E, Lalik V, Veverkova D. Utilization of industrial waste for ferrite pigments production. Chem. Pap. 2012;66:248-258.

4. Koolivand A, Mazandaranizadeh H, Binavapoor M, Mohammadtaheri A, Saeedi R. Hazardous and industrial waste composition and associated management activities in Caspian industrial park, Iran. Environ Nanotechnology. Monit. Manag. 2017;7:9-14.

5. Ahmaruzzaman M. Industrial wastes as low-cost potential adsorbents for the treatment of wastewater laden with heavy metals. Adv. Colloid. Interface. Sci. 2011;166:36-59.

6. Sushil S, Scholz P, Pollok K, Ondruschka B, Batra VS. Application of industrial waste based catalysts for total oxidation of propane. Chem. Eng. J. 2011;166:568-578.

7. Soliman NK, Moustafa AF. Industrial solid waste for heavy metals adsorption features and challenges; a review. J. Mater. Res. Technol. 2020;9:10235-10253.

8. Biswas A, Patra AK, Sarkar S, Das D, Chattopadhyay D, De S. Synthesis of highly magnetic iron oxide nanomaterials from waste iron by one-step approach. Colloids. Surfaces. A Physicochem. Eng. Asp. 2020;589:124420.

9. Dutta T, Kim K-H, Deep A, et al. Recovery of nanomaterials from battery and electronic wastes: A new paradigm of environmental waste management. Renew. Sustain. Energy Rev. 2018;82:3694-3704.

10. Yuan H, Deng L, Cai X, et al. Recycling electroplating sludge to produce sustainable electrocatalysts for the efficient conversion of carbon dioxide in a microbial electrolysis cell. Electrochim. Acta. 2016;222:177-184.

11. Cao Z, Zhang J, Zhou J, et al. Electroplating sludge derived zinc-ferrite catalyst for the efficient photo-Fenton degradation of dye. J. Environ. Manage. 2017;193:146-153.

12. Wang S, Yan W, Zhao F. Recovery of solid waste as functional heterogeneous catalysts for organic pollutant removal and biodiesel production. Chem. Eng. J. 2020;401:126104.

13. Hou H, Liu Z, Zhang J, Zhou J, Qian G. A review on fabricating functional materials by heavy metal-containing sludges. Environ. Sci. Pollut. Res. 2021;28:133-155. 
14. Chen M, Zhou J, Zhang J, et al. Ferrite catalysts derived from electroplating sludge for high-calorie synthetic natural gas production. Appl. Catal. A Gen. 2017;534:94-100.

15. Liao CZ, Tang Y, Lee PH, Liu C, Shih K, Li F. Detoxification and immobilization of chromite ore processing residue in spinel-based glass-ceramic. J. Hazard. Mater. 2017;321:449-55.

16. Gao Q, Wu X, Xia Z, Fan Y. Coating mechanism and near-infrared reflectance property of hollow fly ash bead/TiO ${ }_{2}$ composite pigment. Powder Technol. 2017;305:433-439.

17. Liu B, Zhang S, Pan D, Chang C. Synthesis and Characterization of Micaceous Iron Oxide Pigment from Oily Cold Rolling Mill Sludge. Procedia Environ. Sci. 2016;31:653-661.

18. Du M, Du Y, Chen Z, et al. Synthesis and characterization of black ceramic pigments by recycling of two hazardous wastes. Appl. Phys. A. 2017;123:575.

19. Yuan SJ, Dai XH. Sewage sludge-based functional nanomaterials: development and applications. Environ. Sci. Nano. 2017;4:17-26.

20. Saini D, Aggarwal R, Anand SR, Sonkar SK. Sunlight induced photodegradation of toxic azo dye by self-doped iron oxide nano-carbon from waste printer ink. Sol. Energy. 2019;193: 65-73.

21. Kefeni KK, Mamba BB, Msagati TAM. Application of spinel ferrite nanoparticles in water and wastewater treatment: A review. Sep. Purif. Technol. 2017;188:399-422.

22. Zamare MSD. Biosynthesis of Nanoparticles From Agro-Waste: a Sustainable Approach. Int. J. Engg. App. Sci. Tech. 2016;1: 85-92.

23. Chen D, Li Q, Shao L, Zhang F, Qian G. Recovery and application of heavy metals from pickling waste liquor (PWL) and electroplating wastewater (EPW) by the combination process of ferrite nanoparticles. Desalin. Water Treat. 2016;57:29264-273.

24. Fan S, Wang Y, Li Y, et al. Facile synthesis of tea waste $/ \mathrm{Fe}_{3} \mathrm{O}_{4}$ nanoparticle composite for hexavalent chromium removal from aqueous solution. RSC $A d v$. 2017;7:7576-7590.

25. Heuss-Aßbichler S, John M, Klapper D, Bläß UW, Kochetov G. Recovery of copper as zero-valent phase and/or copper oxide nanoparticles from wastewater by ferritization. J. Environ. Manage. 2016;181:1-7.

26. Huang R, Fang Z, Fang X, Tsang EP. Ultrasonic Fenton-like catalytic degradation of bisphenol $A$ by ferroferric oxide $\left(\mathrm{Fe}_{3} \mathrm{O}_{4}\right)$ nanoparticles prepared from steel pickling waste liquor. $J$. Colloid. Interface. Sci. 2014;436:258-266.

27. Zhang $\mathrm{H}$, Liu J, Ou C, et al. Reuse of Fenton sludge as an iron source for $\mathrm{NiFe}_{2} \mathrm{O}_{4}$ synthesis and its application in the Fenton-based process. J. Environ. Sci. (China). 2017;53:1-8.

28. Visa M, Isac L, Duta A. New fly ash $\mathrm{TiO}_{2}$ composite for the sustainable treatment of wastewater with complex pollutants load. Appl. Surf. Sci. 2015;339:62-68.

29. Visa M, Bogatu C, Duta A. Tungsten oxide - fly ash oxide composites in adsorption and photocatalysis. J. Hazard. Mater. 2015;289:244-256.

30. Visa M, Andronic L, Enesca A. Behavior of the new composites obtained from fly ash and titanium dioxide in removing of the pollutants from wastewater. Appl. Surf. Sci. 2016;388:359-369.

31. Visa M. Synthesis and characterization of new zeolite materials obtained from fly ash for heavy metals removal in advanced wastewater treatment. Powder Tech. 2016;294:338-347.

32. Athalathil S, Erjavec B, Kaplan R, et al. $\mathrm{TiO}_{2}$-sludge carbon enhanced catalytic oxidative reaction in environmental wastewaters applications. J. Hazard. Mater. 2015;300:406-414.

33. Zhang H, Xue G, Chen H, Li X. Magnetic biochar catalyst derived from biological sludge and ferric sludge using hydrothermal carbonization: Preparation, characterization and its circulation in Fenton process for dyeing wastewater treatment. Chemosphere 2018;191:64-71.

34. Zhang D, Luo H, Zheng L, et al. Utilization of waste phosphogypsum to prepare hydroxyapatite nanoparticles and its application towards removal of fluoride from aqueous solution. J. Hazard. Mater. 2012;241:418-426.

35. Kumar R, Sakthivel R, Behura R, Mishra BK, Das D. Synthesis of magnetite nanoparticles from mineral waste. J. Alloys Compd. 2015;645:398-404.

36. Lu X, Ning XA, Lee PH, Shih K, Wang F, Zeng EY. Transformation of hazardous lead into lead ferrite ceramics: Crystal structures and their role in lead leaching. J. Hazard. Mater. 2017;336: 139-145.

37. Lu X, Shih K. Phase transformation and its role in stabilizing simulated lead-laden sludge in aluminum-rich ceramics. Water Res. 2011;45:5123-5129.

38. Lu X, Shih K. Metal stabilization mechanism of incorporating lead-bearing sludge in kaolinite-based ceramics. Chemosphere 2012;86:817-821.

39. Mao L, Cui H, An H, et al. Stabilization of simulated lead sludge with iron sludge via formation of $\mathrm{PbFeO}$ by thermal treatment. Chemosphere 2014;117:745-752.

40. Reddy S, Ho B, Mitoma Y, et al. Sustainable recovery of precious metals from end-of-life vehicles shredder residue by a novel hybrid ball-milling and nanoparticles enabled froth flotation process. J. Clean. Prod. 2018;171:66-75.

41. Liu T, Han X, Wang Y, et al. Magnetic chitosan/anaerobic granular sludge composite: Synthesis, characterization and application in heavy metal ions removal. J. Colloid. Interface. Sci. 2017;508:405-414.

42. Hadi P, Xu M, Ning C, Sze Ki Lin C, McKay G. A critical review on preparation, characterization and utilization of sludge-derived activated carbons for wastewater treatment. Chem. Eng. J. 2015;260:895-906.

43. Liu H, Ji Y, Zhu Y, et al. Converting industrial waste contact masses into effective multicomponent copper-based catalysts for the Rochow process. Particuology. 2018;37:1-8.

44. Costa G, Della VP, Ribeiro MJ, Oliveira APN, Monrós G, Labrincha JA. Synthesis of black ceramic pigments from secondary raw materials. Dye Pigment. 2008;77:137-144.

45. Lee SHM, Lee SHM, Jeong SK, et al. Calcium extraction from steelmaking slag and production of precipitated calcium carbonate from calcium oxide for carbon dioxide fixation. J. Ind. Eng. Chem. 2017;53:233-240.

46. Tanisan B, Turan S. Black ceramic pigments for porcelain tile bodies produced with chromite ores and iron oxide waste. $J$. Ceram. Process Res. 2011;12:462-467.

47. Abreu MA, Toffoli SM. Characterization of a chromium-rich tannery waste and its potential use in ceramics. Ceram. Int. 2009;35:2225-2234. 
48. Tu YJ, You CF, Chen MH, Duan YP. Efficient removal/recovery of $\mathrm{Pb}$ onto environmentally friendly fabricated copper ferrite nanoparticles. J. Taiwan Inst. Chem. Eng. 2017;71:197-205.

49. Li Y, Zhang H, Shao L, He P. Preparation of a metal-phosphate /chromium oxide nanocomposite from $\mathrm{Cr}$ (III)- containing electroplating sludge and its optical properties as a nanopigment. Process Saf. Environ. Prot. 2015;98:261-267.

50. El-Amir AAM, Ewais EMM, Abdel-Aziem AR, Ahmed A, El-Anadouli BEH. Nano-alumina powders/ceramics derived from aluminum foil waste at low temperature for various industrial applications. J. Environ. Manage. 2016;183:121-125.

51. Ahmad I, Siddiqui WA, Qadir S, Ahmad T. Synthesis and characterization of molecular imprinted nanomaterials for the removal of heavy metals from water. J. Mater. Res. Technol. 2017:1-13.

52. Abdel-aal EA, Farghaly FE, Tahawy R, El-shahat MF. A comparative study on recovery of chromium from tannery wastewater as nano magnesium chromite. Physicochem. Probl. Miner. Process. 2016;52:821-834.

53. Liang G, Li Y, Yang C, et al. Production of biosilica nanoparticles from biomass power plant fly ash. Waste Manag. 2020;105:8-17.

54. Munir MT, Mansouri SS, Udugama IA, Baroutian S, Gernaey $\mathrm{KV}$, Young BR. Resource recovery from organic solid waste using hydrothermal processing: Opportunities and challenges. Renew. Sustain. Energy Rev. 2018;96:64-75.

55. Khan FA. Applications of nanomaterials in human health. $1^{\text {st }}$ ed. Springer; 2020. p. 15-21.

56. Zang T, Wang H, Liu Y, Dai L, Zhou S, Ai S. Fe-doped biochar derived from waste sludge for degradation of rhodamine $\mathrm{B}$ via enhancing activation of peroxymonosulfate. Chemosphere 2020;261:127616.

57. Mirzaei A, Neri G. Microwave-assisted synthesis of metal oxide nanostructures for gas sensing application: A review. Sens. Actuators B Chem. 2016;237:749-775.

58. Mondal P, Anweshan A, Purkait MK. Green synthesis and environmental application of iron-based nanomaterials and nanocomposite: A review. Chemosphere 2020;259:127509.

59. Wu C, Kuo C, Lo S. From waste to resource: a case study of heavy-metal sludge by microwave treatment. J. Environ. Eng. Manage. 2009;19:119-125.

60. Duan S, Ma W, Pan Y, Meng F, Yu S, Wu L. Synthesis of magnetic biochar from iron sludge for the enhancement of $\mathrm{Cr}(\mathrm{VI})$ removal from solution. J. Taiwan. Inst. Chem. Eng. 2017;80:835-841.

61. Chen Y di, Ho SH, Wang D, Wei Z su, Chang JS, Ren N qi. Lead removal by a magnetic biochar derived from persulfate-ZVI treated sludge together with one-pot pyrolysis. Bioresour. Technol. 2018;247:463-470.

62. Bandosz TJ, Block K. Effect of pyrolysis temperature and time on catalytic performance of sewage sludge/industrial sludgebased composite adsorbents. Appl. Catal. B Environ. 2006;67:77-85.

63. Akpan UG, Hameed BH. The advancements in sol-gel method of doped- $\mathrm{TiO}_{2}$ photocatalysts. Appl. Catal A Gen. 2010;375:1-11.

64. Parashar M, Shukla VK, Singh R. Metal oxides nanoparticles via sol-gel method: a review on synthesis, characterization and applications. J. Mater. Sci. Mater. Electron. 2020;31:3729-3749.

65. Yilmaz E, Soylak M. Functionalized nanomaterials for sample preparation methods. In: Handbook of nanomaterials in Analytical chemistry: Modern trends in analysis. Elsevier; 2019. p. $375-413$.

66. Cunha G da C, Peixoto JA, de Souza DR, Romão LPC, Macedo ZS. Recycling of chromium wastes from the tanning industry to produce ceramic nanopigments. Green Chem. 2016;18:5342-5356.

67. Boruah PK, Yadav A, Das MR. Magnetic mixed metal oxide nanomaterials derived from industrial waste and its photocatalytic applications in environmental remediation. J. Environ. Chem. Eng. 2020;8:104297.

68. Kong L, Zhu Y, Liu M, Chang X, Xiong Y. Conversion of Fe-rich waste sludge into nano- $\mathrm{fl}$ ake Fe-SC hybrid Fenton-like catalyst for degradation of AOII*. Environ. Pollut. 2016:1-7.

69. Tu Y, You C, Chang C, Wang S, Chan T. Adsorption behavior of $\mathrm{As}(\mathrm{III})$ onto a copper ferrite generated from printed circuit board industry. Chem. Eng. J. 2013;225:433-439.

70. Giri SK, Das NN, Pradhan GC. Synthesis and characterization of magnetite nanoparticles using waste iron ore tailings for adsorptive removal of dyes from aqueous solution. Colloids Surfaces A Physicochem. Eng. Asp. 2011;389:43-49.

71. Mukherjee R, Sinha A, Lama Y, Kumar V. Utilization of Zero Valent Iron (ZVI) particles produced from steel industry waste for in-situ remediation of ground water contaminated with organo-chlorine pesticide heptachlor. Int. J. Environ. Res. 2015;9:19-26.

72. Calderon ARM, Alorro RD, Tadesse B, Yoo K, Tabelin CB. Repurposing of nickeliferous pyrrhotite from mine tailings as magnetic adsorbent for the recovery of gold from chloride solution. Resour. Conserv. Recycl. 2020;161:104971.

73. Jeon EK, Ryu S, Park SW, Wang L, Tsang DCW, Baek K. Enhanced adsorption of arsenic onto alum sludge modified by calcination. J. Clean. Prod. 2018;176:54-62.

74. Lee D, Cho H, Lee J, Huh C, Mohanty K. Fly ash nanoparticles as a $\mathrm{CO}_{2}$ foam stabilizer. Powder Technol. 2015;283:77-84.

75. Mousa SM, Ammar NS, Ibrahim HA. Removal of lead ions using hydroxyapatite nano-material prepared from phosphogypsum waste. J. Saudi Chem. Soc. 2016;20:357-365.

76. Zhou G, Fang F, Chen Z, He Y, Sun H, Shi H. Facile synthesis of paper mill sludge-derived heterogeneous catalyst for the Fenton-like degradation of methylene blue. CATCOM. 2015;62: 71-74.

77. Vignesh Kumar TH, Sivasankar V, Fayoud N, Oualid HA, Sundramoorthy AK. Synthesis and characterization of coral-like hierarchical $\mathrm{MgO}$ incorporated fly ash composite for the effective adsorption of azo dye from aqueous solution. Appl. Surf. Sci. 2018;449:719-728.

78. Chatterjee A, Basu JK, Jana AK. Alumina-silica nano-sorbent from plant fly ash and scrap aluminium foil in removing nickel through adsorption. Powder Technol. 2019;354:792-803.

79. Visa M, Andronic L, Lucaci D, Duta A. Concurrent dyes adsorption and photo-degradation on fly ash based substrates. Adsorption 2011;17:101-108.

80. Visa M, Andronic L, Duta A. Fly ash- $\mathrm{TiO}_{2}$ nanocomposite material for multi-pollutants wastewater treatment. J. Environ. Manage. 2015;150:336-343.

81. Visa M, Carcel RA, Andronic L, Duta A. Advanced treatment of wastewater with methyl orange and heavy metals on $\mathrm{TiO}_{2}$, fly ash and their mixtures. Catal. Today. 2009;144:137-142. 82. Visa M, Chelaru AM. Hydrothermally modified fly ash for heavy 
metals and dyes removal in advanced wastewater treatment. Appl. Surf. Sci. 2014;303:14-22.

83. Visa M, Duta A. Cadmium and Nickel Removal From Wastewater Using Modified Fly Ash: Thermodynamic and Kinetic Study. Sci. Study Res. 2008;73-82.

84. Yang L, Wang F, Hakki A, Macphee DE, Liu P, Hu S. The influence of zeolites fly ash bead/ $\mathrm{TiO}_{2}$ Composite material surface morphologies on their adsorption and photocatalytic performance. Appl. Surf. Sci. 2017;392:687-696.

85. Yang L, Gao Y, Wang F, Liu P, Hu S. Enhanced photocatalytic performance of cementitious material with $\mathrm{TiO}_{2} @ \mathrm{Ag}$ modified fly ash micro-aggregates. Chinese J. Catal. 2017;38:357-364.

86. Bandosz TJ, Block K. Municipal sludge-industrial sludge composite desulfurization adsorbents: Synergy enhancing the catalytic properties. Environ. Sci. Technol. 2006;40:3378-3383.

87. Pan ZH, Tian JY, Xu GR, Li JJ, Li GB. Characteristics of adsorbents made from biological, chemical and hybrid sludges and their effect on organics removal in wastewater treatment. Water Res. 2011;45:819-827.

88. Zhou Y, Fang X, Wang T, Hu Y, Lu J. Chelating agents enhanced $\mathrm{CaO}_{2}$ oxidation of bisphenol A catalyzed by $\mathrm{Fe}^{3+}$ and reuse of ferric sludge as a source of catalyst. Chem. Eng. J. 2017;313: 638-645.

89. El-Sheikh SM, Rabah MA. Selective recovery of chromium ions from waste tannery solution for preparation of chromium oxide nanoparticles. Int. J. Environ. Sci. Technol. 2015;12:3685-694.

90. El-Sheikh SM, Rabah MA. Optical properties of calcium chromate 1D-nanorods synthesized at low temperature from secondary resources. Opt. Mater. (Amst). 2014;37:235-240.

91. El-Sheikha SM, Rabbah M. Novel low temperature synthesis of spinel nano-magnesium chromites from secondary resources. Thermochim. Acta. 2013;568:13-19.

92. Mao L, Cui H, Miao C, An H, Zhai J, Li Q. Preparation of $\mathrm{MgCr}_{2} \mathrm{O}_{4}$ from waste tannery solution and effect of sulfate, chloride, and calcium on leachability of chromium. J. Mater. Cycles Waste Manag. 2016;18:573-581.

93. Morcali MH, Eyuboglu C, Aktas S. Synthesis of nanosized $\mathrm{Cr}_{2} \mathrm{O}_{3}$ from turkish chromite concentrates with sodium borohydride $\left(\mathrm{NaHB}_{4}\right)$ as reducing agent. Int. J. Miner. Process. 2016;157:7-15.

94. Murugan KP, Balaji M, Kar SS, Swarnalatha S, Sekaran G. Nano fibrous carbon produced from chromium bearing tannery solid waste as the bitumen modifier. J. Environ. Manage. 2020;270: 110882.

95. Tu YJ, Chang CK, You CF, Lou JC. Recycling of Cu powder from industrial sludge by combined acid leaching, chemical exchange and ferrite process. J. Hazard. Mater. 2010;181:981-985.

96. Crane RA, Sapsford DJ. Selective formation of copper nanoparticles from acid mine drainage using nanoscale zerovalent iron particles. J. Hazard. Mater. 2018;347:252-265.

97. Mdlovu NV, Chiang CL, Lin KS, Jeng RC. Recycling copper nanoparticles from printed circuit board waste etchants via a microemulsion process. J. Clean. Prod. 2018;185:781-796.

98. Manna S, Prakash S, Das P. Synthesis of graphene oxide nano-materials coated bio-char using carbonaceous industrial waste for phenol separation from water. Colloids Surfaces A Physicochem. Eng. Asp. 2019;581:123818.

99. Liu P, Chen H, Chang X, et al. Electrochimica Acta Novel method of preparing $\mathrm{CoFe}_{2} \mathrm{O}_{4}$ / graphene by using steel rolling sludge for supercapacitor. Electrochim. Acta. 2017;231:565-574.

100. Gaur J, Jain S, Chand S, Kaushik NK. Tin Sulfide Nanoparticle Synthesis from Waste Waters. Amer. J. Anal. Chem. 2014;50-54.

101. Tang B, Yuan L, Shi T, Yu L, Zhu Y. Preparation of nano-sized magnetic particles from spent pickling liquors by ultrasonic-assisted chemical co-precipitation. J. Hazard. Mater. 2009;163:1173-1178.

102. Guo S, Yuan N, Zhang G, Yu JC. Graphene modified iron sludge derived from homogeneous Fenton process as an efficient heterogeneous Fenton catalyst for degradation of organic pollutants. Micropor. Mesopor. Mater. 2017;238:62-68.

103. Novoselova LY. Hematite nanopowder obtained from waste: Iron-removal sludge. Powder Technol. 2016;287:364-372.

104. Weng C, Sun X, Han B, et al. Targeted conversion of Ni in electroplating sludge to nickel ferrite nanomaterial with stable lithium storage performance. J. Hazard. Mater. 2020;393: 122296.

105. Gu L, Li B, Wen H, Zhang X, Wang L, Ye J. Co-hydrothermal treatment of fallen leaves with iron sludge to prepare magnetic iron product and solid fuel. Bioresour. Technol. 2018;257: 229-237.

106. Ren G, Yang L, Zhang Z, Zhong B, Yang X, Wang X. A new green synthesis of porous magnetite nanoparticles from waste ferrous sulfate by solid-phase reduction reaction. J. Alloy. Compd. 2017;710:875-879.

107. Ashrit SS, Chatti RV, Sarkar S. Synthesis and characterization of hematite based calcium rich hydroxyapatite-A nano material from LD slag fines. J. Environ. Chem. Eng. 2020;8:103581.

108. Zhuang Z, Xu X, Wang Y, Wang Y, Huang F, Lin Z. Treatment of nanowaste via fast crystal growth: With recycling of nano- $\mathrm{SnO}_{2}$ from electroplating sludge as a study case. $J$. Hazard. Mater. 2012;211-2:414-419.

109. Wu J-Y, Chang F-C. Recovery of nano- $\mathrm{Al}_{2} \mathrm{O}_{3}$ from waste aluminum electrolytic solution generated during the manufacturing of capacitors. Desalin. Water Treat. 2016;57:29479-29487.

110. Boudinar M, Adjdir M, Bendraoua A, et al. Solidification and stabilization of heavy metal recovered from hydrometallurgical industry waste in the MCM-41 nanomaterial framework synthesized from raw Bentonite. Environ. Nanotechnol. Monit. Manag. 2017;8:268-272.

111. Lu X, Wang F, Li XY, Shih K, Zeng EY. Adsorption and Thermal Stabilization of $\mathrm{Pb}^{2+}$ and $\mathrm{Cu}^{2+}$ by Zeolite. Ind. Eng. Chem. Res. 2016;55:8767-8773.

112. Tang Y, Shih K. Mechanisms of zinc incorporation in aluminosilicate crystalline structures and the leaching behaviour of product phases. Environ. Technol. (UK). 2015;36:2977-2986.

113. Tang Y, Shih K, Wang Y, Chong TC. Zinc stabilization efficiency of aluminate spinel structure and its leaching behavior. Environ. Sci. Technol. 2011;45:10544-10550.

114. Su M, Liao C, Chuang KH, Wey MY, Shih K. Cadmium Stabilization Efficiency and Leachability by $\mathrm{CdAl}_{4} \mathrm{O}_{7}$ Monoclinic Structure. Environ. Sci. Technol. 2015;49:1445214459.

115. Su M, Shih K, Kong L. Stabilizing cadmium into aluminate and ferrite structures: Effectiveness and leaching behavior. J. Environ. Manage. 2017;187:340-346. 
116. Gao C, Yu W, Zhu Y, et al. Preparation of porous silicate supported micro-nano zero-valent iron from copper slag and used as persulfate activator for removing organic contaminants. Sci. Total Environ. 2021;754:142131.

117. Ewais EMM, Besisa DHA, El-Amir AAM, El-Sheikh SM, Rayan DE. Optical properties of nanocrystalline magnesium aluminate spinel synthesized from industrial wastes. J. Alloys Compd. 2015;649:159-166.

118. Ding H, Li J, Gao Y, et al. Preparation of silica nanoparticles from waste silicon sludge. Powder Technol. 2015;284:231-266.

119. Na SH, Shon HK, Kim JB, Park HJ, Kim JH. Preparation and characterization of titania nanoparticle produced from Ti-flocculated sludge with paper mill wastewater. J. Ind. Eng. Chem. 2011;17:277-281.

120. Tsakiridis PE, Oustadakis P, Katsiapi A, Perraki M, Agatzini-Leonardou S. Synthesis of $\mathrm{TiO}_{2}$ nano-powders prepared from purified sulphate leach liquor of red mud. J. Hazard. Mater. 2011;194:42-47.

121. Khalil NM. Exploitation of the ceramic wastes for the extraction of nano aluminum oxide powder. J. Ind. Eng. Chem. 2014;20:3663-3666

122. Yang $\mathrm{H}$, Yan $\mathrm{Y}, \mathrm{Hu} \mathrm{Z}$. The preparation of nano calcium carbonate and calcium silicate hardening accelerator from marble waste by nitric acid treatment and study of early strength effect of calcium silicate on C30 concrete. J. Build Eng. 2020;32:101507.

123. El-Sherbiny S, El-Sheikh SM, Barhoum A. Preparation and modification of nano calcium carbonate filler from waste marble dust and commercial limestone for papermaking wet end application. Powder Technol. 2015;279:290-300.

124. Kolvari E, Zolfagharinia S. A waste to wealth approach through utilization of nano-ceramic tile waste as an accessible and inexpensive solid support to produce a heterogeneous solid acid nanocatalyst: To kill three birds with one stone. RSC Adv. 2016;6:93963-93974.

125. Swain B, Shin D, Joo SY, Ahn NK, Lee CG, Yoon JH. Selective recovery of silver from waste low-temperature co-fired ceramic and valorization through silver nanoparticle synthesis. Waste Manag. 2017;69:79-87.

126. Yousef S, Hamdy M, Tatariants M, et al. Sustainable industrial technology for recovery of cellulose from banknote production waste and reprocessing into cellulose nanocrystals. Resour Conserv. Recycl. 2019;149:510-520.

127. Anawar HM, Strezov V, Hossain MZ. Chapter 5-Comparison of different nanoprocesses and industrial waste-based adsorbents such as red mud, steel slag, and fly ashes for treating wastewater nanomaterial contaminants. In: Emerging and nanomaterial contaminants in wastewater: Advanced treatent technologies. Elsevier; 2019. p. 107-136.

128. Díez AM, Moreira FC, Marinho BA, et al. A step forward in heterogeneous photocatalysis: Process intensification by using a static mixer as catalyst support. Chem. Eng. J. 2018;343:597-606.

129. Szczepanik B. Applied Clay Science Photocatalytic degradation of organic contaminants over clay- $\mathrm{TiO}_{2}$ nanocomposites A review. Appl. Clay Sci. 2017;141:227-239.

130. Duta A, Visa M. Simultaneous removal of two industrial dyes by adsorption and photocatalysis on a fly-ash- $\mathrm{TiO}_{2}$ composite. J. Photochem. Photobiol. A Chem. 2015;306:21-30.

131. Visa M, Isac L, Duta A. Fly ash adsorbents for multi-cation wastewater treatment. Appl. Surf. Sci. 2012;258:6345-6352.

132. Devi MM, Sunaina, Singh H, et al. New approach for the transformation of metallic waste into nanostructured $\mathrm{Fe}_{3} \mathrm{O}_{4}$ and $\mathrm{SnO}_{2}-\mathrm{Fe}_{3} \mathrm{O}_{4}$ heterostructure and their application in treatment of organic pollutant. Waste Manag. 2019;87:719-730.

133. Kahoush M, Behary N, Cayla A, Nierstrasz V. Bio-Fenton and Bio-electro-Fenton as sustainable methods for degrading organic pollutants in wastewater. Process Biochem. 2018;64: 237-247.

134. Gawande MB, Goswami A, Felpin FX, et al. $\mathrm{Cu}$ and $\mathrm{Cu}-\mathrm{Based}$ Nanoparticles: Synthesis and Applications in Catalysis. Chem. Rev. 2016;116:3722-811.

135. MiarAlipour S, Friedmann D, Scott J, Amal R. $\mathrm{TiO}_{2} /$ porous adsorbents: Recent advances and novel applications. J. Hazard. Mater. 2018;341:404-423.

136. Dermatas D, Mpouras T, Panagiotakis I. Application of Nanotechnology for waste management: Challenges and limitations. Waste Manag Res. 2018;36:197-199.

137. Mahmoodi S, Elmi A, Hallaj-nezhadi S. Molecular Pharmaceutics \& Organic Process Research Copper Nanoparticles as Antibacterial Agents. J. Mol. Pharm. Org. Process Res. 2018;6:1-7. 